\title{
The importance of mothers' self cohesion when their children diagnosed were with cancer
}

\author{
Çocukları kanser tanısı almış annelerin kendilik bütünlüğünün önemi
}

\author{
Sema Yurduşen ${ }^{1}$, Canan Akyüz², Faruk Gençöz ${ }^{3}$ \\ ${ }^{1}$ PhD., 2 Prof.,Hacettepe University Medical Faculty, Pediatric Oncology Department, Turkey \\ https://orcid.org/0000-0002-3507-9586-https://orcid.org/0000-0002-7105-4191 \\ 3Prof., Middle East Technical University, Department Of Psychology, Turkey https://orcid.org/0000-0001-7476-1361
}

\section{SUMMARY}

Having a child with cancer has an enormous impact on their mothers. Usually mothers describe their feeling as "losing some part of themselves". In order to understand this traumatic experience on mothers' psychology, psychoanalytic explanations of self/self-cohesion experiences should be taken into account. In this study a comparative case analysis was performed using narrative inquiry and narrative analysis. Two mothers were chosen. Each mother was interviewed about their self-selfobject needs and its relation to their traumatic cancer experience. The narrative analysis revealed that, the mother who had a weak self cohesion before the diagnose reported more traumatic narratives in comparison to the mother who had a healthy self cohesion. Not all mothers with children who has cancer were affected to the same extent from this traumatic experience. Understanding mother's earlier and present selfobject transferences will help clinician to intervene to the right person. Understanding mot-hers' distress from the psychoanalytic perspective and intervene at that level not only improve mothers' well-being but also the children's and the society's at large.

Key Words: Mother, self, selfobject, childhood cancer, narrative

(Turkish J Clinical Psychiatry 2020;23:214-228)

DOI: $10.5505 / \mathrm{kpd} .2020 .82612$

\section{ÖZET}

Kanser tanısı almış bir çocuğa sahip olmanın anneler üzerinde muazzam etkileri vardır. Genelde anneler duygularını "bir parçamı kaybediyormuşum gibi" şeklinde tanımlarlar. Bu travmatik deneyimin annelerin psikolojileri üzerindeki etkilerini anlamak için kendilik/kendilik bütünlüğü deneyimleri olarak anılan psikanalitik açıklamalar dikkate alınmalıdır. Bu çalışmada öyküsel sorgulama ve öyküsel analiz yöntemi kullanılarak karşılaştırmalı vaka analizi yapılmıştır. Çocukları kanser tanısı almış iki anne ile yaşadıkları travmatik deneyimler ve bunların kendilik-kendiliknesnesi ihtiyaçları ile ilişkisi konusunda görüşmeler yapılmıştır. Çocuğu kanser tanısı almış tüm anneler bu travmatik deneyimden aynı düzeyde etkilenmemektedir. Annelerin geçmiş ve şu andaki kendiliknesnesi aktarımlarını anlamak klinisyene doğru kişiye müdahale emesi için yardımcı olacaktır. Annelerin yaşadığı stresi psikanalitik bakış açısı ile ele almak ve bu düzeyde müdahale etmek sadece annelerin iyilik halini yükseltmeyecek aynı zamanda çocukların ve daha büyük ölçekte de toplumun iyilik haline katkıda bulunacaktır.

Anahtar Sözcükler: Anne, kendilik, kendilik nesnesi, çocukluk kanserleri, öykü 


\section{INTRODUCTION}

Cancer diagnose and treatment has been one of the most stressful life events an individual can experience. Besides, the anxiety of the possibility of losing a loved one has an immense effect on the wellbeing of those close relatives. When the person who has cancer is a child and the caregiver is a mother, then, the impact of the burden increases. In practice, it is not uncommon to hear mothers who have a child with cancer saying that "they feel like they are losing a part of their self". Mothers may consistently suffer from psychological problems or experience constant threat to their selfcohesion (1). They mentally or emotionally suffer from watching their children suffering (2) and when mothers' well-being or self-cohesion is shattered following diagnose, the child suffers from this, too.

However, very few studies focused on the impact of diagnose and the possibility of losing a child with cancer on self cohesion of mothers. In order to understand this traumatic experience on the psyche, one should focus on psychoanalytic explanations of self/self-cohesion experiences.

Self is conceptualized as a developmental process or mental system that organizes person's subjective experience in relation to a set of developmental needs (3). Kohut (4) suggested that self is composed in relation to others (selfobjects) who are experienced as part of the self. These self and selfobject relationships exist from birth to death and as long as the individual experience others as people who respond willingly, who provide an idealized power and tranquility and who is able to grasp the individual's inner world more or less correctly, the person experience himself as cohesive, adaptive and consistent unit. He feels connected to the past and creative and productive for the future (4). Kohut asserts that these self-selfobject relations are necessary conditions for the healthy development of the person. If these needs are not met sufficiently in the early years of the life, people suffer from self disorders and depends on emotionally attuned selfobject responses throughout their life. Kohut named these basic longings for selfobjects as "archaic selfobjects" (5).
When everything goes well optimal "structuralization" of the self is formed and it permits the individual to have an autonomous existence to a degree but, following Kohut, Ornstein (6) pointed out that "there is no complete autonomy at the end of the developmental line" (p. 202). Different selfobject needs persists throughout life either to maintain a cohesive self or to repair the disrupted self in order to give its vitality. Thus, in dyadic interaction "selfobject transference reflects insufficiently or faultily structuralized self as this appears in the patient's subjective experience and behavior" (p. 202). These needs may be observed either with speechless covert behaviors or with overt strength of the person's demandingness or avoidance. Understanding these developmentally unmet needs, in the expression of the hope to strive to repair these needs through the therapist' responsiveness, "this opportunity insufficiently provided to the analysand in childhood that is offered once more by analysis" $(4, \mathrm{p} .210)$, is a crucial step for healing of people who suffer from moderate to severe self disorders. Thus, especially at the beginning of the therapeutic process, the patient with narcissistic injuries needs to experience the therapist as part of his/her self or needs to experience himself as part of the therapist's self. Ornstein (6) stressed that in psychoanalytic psychotherapy understanding the patient's inner experience through empathy is the main tool in order to establish a cohesive, healthy and adaptive self.

Kohut $(5,7,4)$ hypothesized three different self object needs that are developmentally necessary to form a cohesive and healthy self. These needs are a) the desire for recognition, b) the need to merge with an idealized subject and c) the need to experience friendship or connection. Kohut named these needs as mirroring, idealizing and twinship.

The mirroring experience can be defined as the parental acceptance of child's age-appropriate grandiosity and his/her responsive attitude to this need $(5,7)$ so that the child can maintain positive and stable self esteem. It is the mirror in the mother's eye that the child needs in this time of development. Any insensitive, unemphatic response during this early period of development may result in primary narcissistic injury and may cause grandiose defenses against dependency. A person with this 
type of narcissistic injury would be in hunger for mirroring from others for the later years of the life (see 8). The idealizing experience on the other hand is another way of maintaining a stable self esteem through a system of goal setting ideals (5, 7). An individual who needs an idealized selfobject wants to merge with the idealizable figures in order to form a cohesive self. This need can also be used as a compensation for primary narcissistic injury caused by early unmet mirroring needs. In other words, the parents' and usually the mother's traumatic failure of meeting the grandiose needs may be compensated by other parent's ability of being an idealization figure. However, both mirroring and idealization needs can be met only with one parent too. Any emphatic failure on responding to idealization need during crucial phases of development is accepted as a secondary narcissistic injury. Basically, Kohut $(5,7)$ regarded these needs as the basic narcissistic needs and if somehow these needs are not responded for example by the physically present but emotionally absent mother or by an unexpected loss of a father, a healthy self-development gets arrested and pathological narcissism occur. Thus, people with these archaic needs become dependent on others' reactions so that other people are needed in order to mirror their grandiosity or as objects to be merged for idealization.

During the development of his theory, Kohut (4) defined another need called twinship which lies in the middle area between mirroring and idealization. It is defined as a sense of essential alikeness and a sense of being a human among other human beings (9). It was noted that pathology which is presented as the loss of feeling vital results from this lack of human contact.

Kohut (4) stated that if one of these needs is not responded emphatically during early childhood, the self is experienced as fragmented or feeling empty. Thus, he concluded that all forms of psychopathology result from the disturbance of these self-selfobject relationships during childhood. Recently, Ettensohn (8) pointed out the feeling of fragmentation in response to disturbance of mirroring and feeling of emptiness and depression in response to disturbance of idealization. Consistently, in a study done by Vipond (10) on 159 university students, the strength of the selfobject needs is found in relationship to the vulnerability of self fragmentation both in patient and student groups. She stated in accordance with Kohut that "the strength of selfobject needs is related to how archaic these needs are" (p.45).

Even though people were not suffered from self disorders, Wolf (3) and Ornstein (6) noted that people need temporary selfobject responses during life's adversities such as experiencing an illness or facing death (cited in 4, p.287). Thus, even though a person developed a stable and cohesive self and did not experience any early relational trauma, the relational experiences after life's traumatic events may render individuals narcissistically injured. Togashi and Kottler (9, p.346) also defined this by saying that 'Kohut's theory has changed from psychology of the self-pathology to psychology of pathology as a result of trauma'. They said that after a traumatic event an individual's feeling of human being among other human beings gets lost and an intense search for a sense of alikeness, sameness or kinship with others follows. If this attempt is not satisfied than the person feels as non-human being which can be accepted as a secondary reaction to trauma, as also noted by Brothers (11).

Literature investigated selfobject experiences mostly from the case studies at different areas (i.e., $12,13,14,15,16,17,18)$. Among the limited research, Allen (19) reported that there is an increase in selfobject needs among gay man where there is an increase in homophobic and heterosexist discrimination. He stated that the unmet selfobject needs in case of discrimination results in feeling of being under observation, shame, depression and anxiety. In addition, a qualitative study (20) investigating self and selfobject experiences in 7 mothers of children with autism who were aged between 6 and 11 , reported that mothers experience frustration of selfobject needs in all sort of relationship. According to that study, mothers' frustration appears between professionals, community, friends, spouses and extended family. Their reported frustration mostly occurs in the area of acceptance and understanding. They usually experience rejection, criticism, judgment from people, frustration about losing ideals about parenthood and 
being a 'provider' selfobject function for their child and they lose mutuality with their child. This study is important about highlighting the importance of selfobject needs among mothers with chronically ill children. Moreover, if mothers' unmet selfobject needs are related to their earlier life experiences, this would possibly render mother-child dyad more vulnerable.

However, to the best of the authors' knowledge, there is no study investigating selfobject experience of mothers whose children diagnosed with cancer. Since many mothers may potentially experience disintegration or fragmentation anxiety (see 12) during and after this traumatic event, understanding the presentation, function and meaning of those experiences together with their earlier self experiences would provide clinicians more accurate intervention. Thus, the aim of this study was to explore the mothers' personal stories about their sense of self during their children's cancer treatment.

\section{METHOD}

Narrative inquiry is interested about how people interpret others' and their own actions in a storied fashion. Throughout the stories people give a coherent meaning into the chaotic life events. Narratives are our way of shaping the world and shaped by them (21) and interpretation of the separate events in the formation of completeness and how we present those stories are very much related to our identity. The content and manner of the storytelling defines ourselves. Since selfobject experiences are best understood in terms of relational stories, it is believed that narrative inquiry is the best method to understand the mother's level of self cohesion.

Riessman (22) explains the models of Narrative Analysis in four typologies named as thematic, structural, interactional and performative analysis. These types are not hierarchical, "different approaches can be combined, they are not mutually exclusive and as with all typologies boundaries are fuzzy" (p.2).

In thematic analysis the researcher attempts to identify "what is said" and what was the meaning of those stories; in structural analysis, besides "what was said", "how it was said" is also emphasized; in interactional analysis, the interactional process between the teller and the listener is also investigated and; in the performative analysis the unspoken words or gestures are taken into the consideration (22).

In summary, "narrative inquirers are interested in how storytelling activities are (contextually) embedded, what they consist of, and how we can take their form, content, and context as cues toward an interpretation, what the particular story meant, what it was used for and what functions it was supposed to serve" $(23$, p.202).

\section{Sample/Data Collection}

We designed a comparative case analysis in order to enlighten mothers' identity/self issues during their children's illness process. For this, two mothers of children who has been treated at Hacettepe University Hospital, Pediatric Oncology Department, Ankara, for at least two months, were chosen. Child's age and his/her physical strength to act independently were taken into account. Before the interviews were started, written informed consent was taken from the mothers about the nature of the study. For each mother, a series of interviews were done in the hospital -each is about 50-minute length- and all interviews were recorded by permission. The interviews were transcribed verbatim.

For the interviews, we established a series of questions about mother's present cancer experience and their earlier difficulties in the light of self-selfobject experiences. We used episodic interview so that we could identify mothers' past and present relational experiences during traumatic events. In this approach, rather than asking selfobject needs (idealization, mirroring, twinship) directly, we focused on the themes of the stories and the interactional and performative function of those stories. For this aim, after asking the first question the interviewer directed the respondent by selecting the themes that she wanted to study. Thus, our questions broadly consisted of as follows; "Can you tell me about your experiences during your child's illness 
and treatment process?", "Have you had any other difficulties before and if yes, how did you cope with them?", "What would you tell about your relationship with your family members now and before?", "Can you remember and describe a time from your childhood that you lost something important to you?".

\section{Ethical approval}

Ethical permission was received from Middle East Technical University's Ethical Committee (28.11.2014/28620816/565-1674 ). This study was also supported by the Scientific Research Commission of Middle East Technical University, Grant No: BAP-07-03-2015-017.

\section{Trustworthiness.}

Criteria for qualitative studies' trustworthiness (reliability and validity) refers to the findings of research study's credibility, transferability, confirmability, and dependability (24). For narrative inquiry studies, the criteria for trustworthiness refers to the characteristics of appearance, verisimilitude and transferability (25). Loh (26) pointed out that using member checking including verisimilitude and utility of the narratives are good points to start.

For the aim of member checking, first the authors investigated, discussed and reflected on the narratives about how participants described their sense of self during their children's cancer treatment. After, we used peer validation by sending the narrative analysis to the peers and had their agreed and non-agreed views about the interpretations we made and then, we reviewed and re-analyzed our interpretations according to those feedbacks. Our peers suggested about interpretations as being useful and deepening their understanding of self-psychology. For the aim of verisimilitude, we also considered other mothers' feedback whether the narratives' seem 'real' and 'alive'. All mothers we asked responded that the narratives about diagnose and treatment were very similar to their experiences.

\section{A Comparative, Narrative Case Analysis (What- How-Why)}

\section{Case 1 (Nihal)}

The first participant was 45 years old mother (nicknamed as Nihal) with three daughters. When we started to make interviews, her third daughter (nicknamed as Dilek) aged 10 had been started having chemotherapy treatment for solid tumor in her abdomen, for 3 months. Nihal was first met during the first chemotherapy treatment of her daughter in the inpatient ward. She was asked to join weekly interviews and to talk about her general experiences both her child's illness and her earlier life difficulties. She accepted but with hesitation. After the mother's informed consent was taken about the nature of the study, she was interviewed weekly sessions for 5 times and all sessions were video recorded. The first impression of her in the inpatient ward was her anxious eyes and her despair which are very typical for the mothers in this setting. In the first interview same anxious looking eyes were present also wondering about the interview content and manner. After briefly repeating the aim of the interviews, I asked about her experiences with the question as, "Can you tell me about how are your experiences during your child's illness and treatment process?"

From the first moment she responded briefly as "I am not living". This was the major theme that she reported very often during the sessions. She has not been feeling alive since diagnose.

Below related transcripts of the interviews was written;

Transcript Nihal-1: I am not living for 3 months. I am not living, I am not living. I am not aware that I am living (crying). Everything is Dilek. When we found out this illness, the life stopped for us. At the beginning, from the emergency, the risk gradually increased. We came with stomach ache and the severity of it gradually got expanded and the procedure ended up with biopsy. After all, the biopsy was our turning point. Before the result of the biopsy, I prayed as "my god, please don't let the bad things happen. God forbid! God forbid!"... and suddenly 
we were faced with it. We were in the middle of the things that we tried to escape. That was the turning point.

In her account of the cancer diagnose experience she began to speak in the present tense emphasizing that she is not living as if saying that without her daughter she also feels dead. In the second attempt, she explains this with the past tense which explains that there was no life after her child was diagnosed. In almost two sentences, she abstracted how the life was for her and how this experience severely traumatized her vitality. Then, gradually she gave more detail about the events by orienting me about how each detail in this process has important impact on her and telling her desperate need to nestle someone stronger that is God. That was the first clue of her hunger for idealization. She was hurt with the harsh reality that there was no getaway and this automatically led her to look for an idealized selfobject, here in the name of the God. Below the transcription of her follow up talk about how she feels.

Transcript Nihal-2: Yes, we found ourselves in what we tried to escape. The "life" stopped for us. We didn't live anymore. The life stopped for us. Everything went upside down. Our home life, our routines, we didn't even smile and we had to do role playing. Everything evolved without Dilek's knowledge. I didn't want her to know her illness. Since she is very smart, I thought she was going to ask many questions and she might have make up a different world in her mind. She is a very positive child. Very cheerful. I didn't want her joy to end. I didn't want her to learn her illness. Thus, we acted as if nothing serious happened, we all had to role play and this made me so tired. Still makes me tired but for my child, it doesn't matter how tired I am. We hope that once she is cured, the treatment is ended and then we will start living again. Once we hear from our doctor that, everything went fine, the treatment is finished and the control appointments are started, we will start living again from where we left.

From this passage it is understood that the mother's primary feeling was being dead with her child's mortal illness which she felt the need to hide it on behalf of her child. Thus, she was acting within two selves one for fake (as if alive) and one for real (dead self). From the grief studies perspective this stage was defined as shock and the selfobject function of the child for the mother is threatened by the child's death. Hagman (27) describes this situation as a rupture of the selfobject bond where there is a fortification of self through acting alive in response to danger of disintegration. What she tells me in the interview was how hard she tried to save her daughter's physical and psychological well-being through role playing despite of her real dead-self feeling. Riessman (28) notes that "Stories, more than other forms of discourse effectively pull the listener into the teller's point of view. They re-present a slice of life, often by dramatizing and reenacting a particular interaction, thereby providing 'proof' of how it was. They draw the listener so deeply into the teller's experience that often a kind of inter-subjective agreement about 'how it was' is reached" (p.1197). Thus, beside the central theme of feeling dead, by effectively inserting her effort she drives the listener's attention of her struggle between her fragmented selves and her desire to be real and alive. For this, she seemed to try to provide idealized selfobject to her child so that she can feel alive through her aliveness. She was transferring her lack of self cohesion in the expression of needing idealized selfobject needs (ex. praying God) and through being an idealized selfobject provider for her child. From the interactional perspective, her unspoken words, looking and body language also gave the impression that she needed others (i.e., listener) to rely on, others who can help her by staying strong that she can merge with. She was searching selfobject responses to overcome with this grief which caused disintegration of her psychic organization (27).

Transcript Nihal-3: Sometimes we hear negative information from the doctors. "God forbid" things can get worse, but when we leave the doctor's office, meeting Dilek, we have to clear our mind from all exhausting thoughts and, I have to act as a mother who thinks that everything is fine, the treatment is so well, you are so well, you can do this, you can achieve this, you can beat this. I have to act as this kind of mother. She needs to see that kind of mother. That kind of mother she needs to see. But on the other hand I am fighting in my mind. 
Transcript Nihal-4: All priorities are belong to Dilek now. She needs me more than she needs her sisters or father. Thus, I have to devote all myself, my body to her. I am giving myself to her, I devote myself to her.

Being idealized selfobject (strong-devoted mother) appears as a compensation of her need to idealize to feel whole and alive. That theme appeared very often in her other narratives. . It is seen that, Nihal has difficulty at accepting the reality of loss and trying to restore her disintegrated self-psychic organization by acting in the opposite direction (27). She was not only mourning to the child who is dying but also fighting with the reality by ignoring and acting in the opposite. At this point, I wanted to explore the function of this over compensation further by investigating her real but dead-weak self.

Transcript Nihal-5: Nobody wants to know real Nihal. I don't know, a sad, mournful mother .... She is in her own world, in her own mind...nobody wants to know her...a sad person who fights with her own problems by herself, it is as such...

Here, again the described theme dead self explained as alone-isolated self of whom nobody understands or wants to know. She described these feelings of isolation and devotion with one words as "using a mask". She has not been mirrored by her environment through recognition, so that she seemed to create a false (as if) self who is using a mask. Apparently, up to now, in order to satisfy her archaic needs of mirroring selfobject responses, she was using her own children. Now, her self-psychic organization is shattered because of the possibility of losing her child and she created invisible mask for compensating her selfobject needs.

Transcript Nihal-6: When the sun rise, we put on our masks again, a very happy Nihal comes. In order to keep Dilek full with life energy, I try to keep her away from other people. I don't want to hear any absurd words from other people. That's why I don't want to meet with people.

Even though she was describing the dead feeling and using a mask after the diagnose, it seemed that this feeling was there earlier than this illness. In her expression that "nobody wants to know her", she was implying that she was isolated from everyone even before diagnose and was trying very hard with whom she can be an idealized selfobject which can make her "someone who is alive". In terms of interactional analysis perspective in which the meaning is created between parties, that description again impinged upon me that she needed somebody who just stays with and understands her. She needed somebody that mirrors her own being through knowing or understanding her. As Banai, et al., (29) reported, people with chronic hunger for mirroring and twinship tended to be more severely hurt especially during the times they feel helpless. With this background of hunger for mirroring, Nihal seemed to be hurt very much. Her hunger for mirroring was also appeared in her interaction with her older daughter.

Transcript Nihal-7: At home, we talk to each other with our eyes. We listen to each other with our eyes and, when we look each other, we can understand what we meant to say. We take our masks from each other.

Even though, Nihal wanted to be mirrored, she did not seem to benefit from others except of her daughters. Rather, she was avoidant with people in her social environment.

Transcript Nihal-8: Since we are giving each other the glad eye, I do not need anyone else. Because others don't understand. I don't expect them to understand me. They cannot understand me. Only people who can understand me were those who get the same treatment. Only, these people can understand me. Because, here, it is a very different world, very different, I don't want anyone to live this. I don't want my neighbors or friends to understand me. Only those who experience this can understand this.

Transcript Nihal-9: A while back, my husband became ill. I was so sad, I always lived my sadness in my mind. I am not someone who shares her sadness with others. Talking to people who doesn't understand me makes me more tired. Maybe, I told the same thing before but as I said, when people does not understand me I got more tired, I try to 
explain myself and when I can't, it makes me feel more tired, then I don't want to talk, I mean in my mind, when the night comes and children are sleeping, I listen to myself in the emptiness, then the real Nihal comes out, when the children asleep the real Nihal who does not put any mask, who is not playing happiness comes out. In the quietness, I am looking with empty eyes, watching TV without awareness of what I watch. As if a motor which works continuously till the night and as if when you plug out the cable it leaves itself for resting, so mine is such a mothering.

Overall, those short narratives tell us that, Nihal was impacted by this traumatic experience very deeply and felt so alone inside. She was fragmented by the reality and tried to stay intact through as if using a mask during days. Using this mask both help her to be an imaginary idealized figure for her child and a vehicle for herself to feel some sort of aliveness. However, carrying this mask was very difficult for her and she was exhausted at the evenings. During the normal mourning process, in order to have a cohesive and vital self, the bereaved person should be able to transform and adapt the lost person's selfobject function into her self-structure (27). However, in Nihal's case, feeling vital seemed to depend on her needs to be understood and cared by people who lives and understands the impact of this experience. Since she couldn't meet these archaic needs in her environment she was compensating them by playing as an idealized figure through using an imaginary mask (selfobject provider) for Dilek.

Thus, together with her earlier themes that 'dead feeling', 'using a mask' and with 'avoidance of understanding, we conceptualized her "self" as someone who has hunger for mirroring, idealizations or twinship but avoidant of others' responses because she believes that those needs could not be satisfied. In order to overcome this aloneness and helplessness, she was trying too much to be an idealized figure for her child. Thus, her story of diagnose and treatment experience let me ask the question of why she was avoidant of mirroring or recognition from others except for her older daughter.

Before furthering Nihal's past selfobject relations during earlier life difficulties, we must present sec- ond case in order to understand the impact of the cancer diagnose and treatment on the second mother, again considering the self psychological perspective.

\section{Case 2 (Pınar continued)}

The mother was 46 years old (nicknamed as Pinar) with an only son aged 8 (nicknamed as Burak). We first met and talked right after the cancer diagnose of his son. At that time, she was very tense, unknowing the processes that waits for her in the future. The first interview of the research was made around three months after diagnose. Until then, Burak had been having chemotherapy treatment for his solid tumor in her temporal side for at least 2 months. When I asked the mother to join the interview and had her informed consent, she accepted it in a manner as a helper though she was a bit anxious. She was interviewed 2-weekly sessions and both sessions were video recorded. The first impression of her in the interview was her readiness to help me. After briefly repeating the first question of the interviews by asking, "Can you tell me about how are your experiences during your child's illness and treatment progress?" she responded with flat talking about what she had been through. Below the first transcript of her experiences was written.

Transcript Plnar-1: The experiences were quite hard for us. At the beginning we started with a shock. We did not know anything. We were as if in a dark tunnel, thinking of where to touch, what to do, how come we can stay strong, .... but, everything starts with acceptance.... at first you protest, react against everything but you can't find any solution... at the end, you accept and start to fight. After that acceptance, things get easier, and reaction stays behind.

From this brief explanation, we understand that Pinar went through a difficult times but ended up with accepting the reality. She had a very mature way of interacting with me. Rather than needing a help, she was the one who was helping me. From the performative analysis perspective, in which storytelling is seen as performance which persuades and moves the listener through language and gesture (22), she had an attitude of an informer. There 
was no clue about her hunger or avoidance for selfobjects. The only remarkable thing was that she was talking without strong emotions. In comparison to the first case, even though they both experience more or less the same events, the second case seemed more self-sufficient. Following transcription highlights her experience in a bit more detail.

Transcript Pinar-2: Sometimes, the question 'why?' comes forward. However, after you talk with other families, or people with similar experiences... somehow, when you get into the experience, you let yourself into that water and, you do and search for whatever you can...after that searching, opportunities appear correct or false and, you use your judgment to decide which decision is better, with what we can be more successful... and finally, we arrived fourth cure and we had quite a lot of experience, and we will have more experience...

Here, Pinar explained her way of coping. From the self psychological perspective, she seemed as someone who has a cohesive self. Contrary to Nihal, she was actively searching for help and seemed to benefit from people who had the same experience. She did not seem to depend on archaic selfobject responses. She seemed to have optimally responsive selfobjects in the early years of her life. Thus, rather than staying in the melancholic state she was able to restore her affected self-structure through others' presence (27).

Transcript Pınar-3: Of course, it was too hard. It took days to accept. I received help from a relative who is a psychologist. Talking with her helped me, but, the first time I heard diagnose, I was shocked, I did not accept it. I asked as 'why that happened to me?'. You cannot accept, you wait for a miracle as if nothing happened and I did not live these through. I couldn't sleep for days about a month, it was not easy. Sometimes, I still ask again 'why?' but I started to overcome with it.

As we can see, Pınar also experienced very hard times during processing the harsh reality but she was somehow stronger than Nihal. Contrary to Nihal's feelings of 'alone, isolated, fragmented self', she described her self as someone who accepts the reality and looks for the ways to over- come with it, with her feelings of 'determined-coping self'. With this attitude, she seemed to benefit from mirroring, idealization or twinship experience from her relative and people from this setting. Below, her words about the relationship experiences are written.

Transcript Pinar-4: My psychologist friend had also experienced a similar event. She helped me a lot. She is quite older and have more experience than me. She was about to lose her daughter after a traffic accident and the daughter is living as handicapped now, but, she holds on to life, her daughter also holds on to life.

Transcript Pınar-5: I have also my mother, my father, my cousins. I am not alone. We get into this process together. They help me a lot. I am very good both with my mother and father. We live together at the moment. I always get on well with them. I am the only child. Burak is an only child, too. But, I have good relationships with my relatives, I have strong connections. I also have friends who are not psychologist but who can support me. Both their help and our belief will help us to overcome with this.

Transcript Pinar-6: At the beginning, I was in shock, I wanted to be isolated from people but afterwards I understand that this was not a good idea. Because, if people get socialize, be in interaction with others, but with correct people, the problem is solved quicker. Talking when necessary, making gossips sometimes are the biggest healing attitude. My personality is also like this. The more I talk and don't keep the problems with me, the better I feel and the happier I am. Sharing with people but with correct people.

Transcript Pinar-7: There were people that I expect them to call or send a message but they did not do anything, so, I left them as they are. Other people whom I did not expect were interested. It is maybe others' limited capacity or they wanted to perceive things like that, maybe they wanted to help by leaving me alone...I noticed that people I can communicate gets lessen in number but I have a key staff and I am in interaction with them. 
In her all stories, even though she explained her difficult life issues, she finished them with some positive concluding remarks which implies her coping strength. From the self psychological perspective, one of the factors that was thought to be helping was idealization. Both Pinar and Nihal had strong beliefs in God. It is not surprising that they mention their idealization to cope with the situation because real dangers in the world let people to look for someone to cling into (27).

Beside this idealization, Pinar emphasized her satisfaction with people around her that helped her mirroring needs to be responded to. As Nihal, she also had disappointing experiences with people but this did not seem to cause her to put some distance between people. She simply accepted them as they are and kept walking his life with those around her (see Transcipt-Pınar 4; 5; 6; 7). However, for Nihal this was not possible. She was deeply affected by people's ignorance and tried to keep herself away from them to be able to stay strong (see TranscriptNihal $5 ; 6 ; 8 ; 9)$. Another difference between these mothers was, Pınar's searching for and sharing with correct people but Nihal's inability to use these relations. Again, Pinar seemed to benefit from twinship experience (see Transcript-Pınar 4;8) but Nihal couldn't. Below, some of Pinar's thoughts were written about her way of looking and handling the situation.

Transcript Pinar-8: Nothing is resolved alone in this world. You need to share. I myself, reached the hands of people who thrust their hand on me and I put myself in, so together I try to solve this problem. At the beginning, I needed this more but later I prayed too. Both support, praying and my relationship with God helped me.

Considering two mothers together, as Riessman (30) pointed out, 'it was not the events by themselves that were traumatic, but the interpretation placed on them by the narrator-meanings that are built into the dramatic structure of the narrative itself' is traumatic (p.746). However, it is believed that, the interpretation of the impacts of the traumatic events cannot be free from the narrator's level of self integration. With Nihal's and Pınar's experiences, we understand that Kohut's suggested ideas of mirroring and idealization selfobject needs naturally reappear during these traumatic experiences. However, the presentation of these needs may differ from person to person depending on the earlier life experiences. While Nihal's needs and avoidance of selfobjects render her more vulnerable and led her to interpret the traumatic event as hard to cope; Pinar's satisfied selfobject experiences led her to interpret the same event in a more realistic way, thus helps her to overcome with the difficulty. While Nihal was affected from negative responses of people, Pinar seemed to be free from depending on these responses. In order to clarify the reasons of these mothers' selfobject needs presentations we questioned further about their earlier life difficulties. So we asked as, "Have you had any other difficulties before and if yes, how did you cope with other difficulties before this experience?", "What would you tell about your relationship with your family members now and before?".

\section{Case 1 (Nihal continued)}

As expected, Nihal's feeling of aloneness was not a new one. When her husband had a stroke about ten years ago, her devoted self appeared again but this time for her husband.

Transcript Nihal-10: When my husband had a stroke, in the hospital, I was staying with him during the days. At night other people were staying but I did not want to leave him any time. I forget my children, everything. After the hospital, I closed down my house, started to stay with my mother-inlaw. We did not accept anyone at home. I was looking after him nights and days. I was helping him to make his physical exercises. Most of the time I didn't see my children. My husband H. had been waiting for me. He had been looking at me in the eye as saying 'come quick'. At the end, we made him to get up on his feet again.

This story and the way the story told, led me think that, Nihal again acted as the devoted woman at the expense of not seeing her children. It was like she experienced present trauma years ago. This was her way of reacting to traumatic events. She tries to become a sufficient woman who does not need anyone else. However, behind this self-sufficiency, her 
need to be in need by someone, in order to be seen by him was remarkable. Following transcript highlights her devotion and suppressed needs of being seen.

Transcript Nihal-11: When my husband in the hospital, I told them that 'visiting was forbidden for H., but not for me. You could have visited me', 'seeing was forbidden for him but not for me. You could have come and see me'.

As mentioned, her devotion seemed to function as a way of getting the recognition she needed. Her self cohesion seemed to depend on other's responses very much. She was an alone mother who finds the meaning by devoting herself to her family. Beside the scope of her stories, her way of telling (repeating the events and experiences many times with every detail), and looking me in the eye also led me think of her need of assurance and understanding. In her all stories, she was giving the same message that she needed recognition from her close family. Beside, since she needed this attention, she believed everybody needed that. In order to find a solution to this problem, she was devoting her self to others which renders her so exhausted, at the end. Hagman (27) and Ungar and Levene (31) notes that, optimally mourning occurs in the context of emphatic, supportive and self-sustaining environment, family and spouse. Without this social milieu, the bereaved may not do well.

With these stories in our mind, we were curious about her earliest life environment and what kind of a child she was especially in times of distress. It was believed that these all mirroring needs must be caused from earlier mother-father-child relationships $(7,4)$. So we asked her as, "What would you tell about your relationship with your family members now and before?" and "Can you remember and describe a time from your early childhood that you lost something important to you?".

Interestingly she could not report any significant moment in her relationship with her parents by reasoning that she was the youngest of six siblings. Even this 'not remembering' led me to verify my thought that she was an alone child with whom she was not mirrored or did not idealized. She reported her relationship between her mother and father as following;

Transcript Nihal- 12: What can I say? We brought up under pressure. My father never slapped us but he would beat up with his glance without moving his hands. I don't remember my father's beating but he wasn't someone who shows his love. I don't know whether he liked us. We were scared of him; my mother brought us as to have us scared of him. She was telling that 'you are a girl'. My brothers were fathering us. They were stepping into our lives.

Nihal's summarizing her relationship with her parents was impressive. She was born into a family where she did not feel that she was welcomed, where she could not find any space to be as herself with others' through optimal mirroring, idealization or twinship experiences. So, she seems to be in search for mirroring, or people or beliefs to idealize in her life especially during traumatic experiences where she might potentially lose all she has. However, she remembered her older sisters' marriage as a loss and describes the situation with the following sentences.

Transcript Nihal-13: My older sister got married when I was in 2nd grade in primary school. I loved her very much. I remember crying a lot after she got married. I was deeply sad and found a hidden corner to cry. I felt so alone; I did not have many friends. She was like my friend and I was so upset after her marriage. I wanted to see her but I couldn't see. I was alone and I did not want anyone to see me. I was going that corner and crying alone. You know, I just recognized, I am the same know. I was 7 and I am almost 47 years old now. For 40 years I am the same and I don't want anybody to see me.

This story of her childhood was very enlightening. She was an alone child who suddenly lost her best friend in the family and found no one to share her feelings with. She again, did not want anyone to see her because there was nobody to carry her feelings. Thus, her feelings of fragmentation, devotion at this present loss and desperate hunger which is presented as avoidance for understanding and recogni- 
tion might be related to her earlier feelings of sudden selfobject loss. In other words, her primary narcissistic injuries seem exacerbated in this present narcissistic injury. Without understanding this connection, it would be not possible to provide her necessary attitude. Hagman (27) notes that "pathological mourning will result when the nuclear self is primarily organized around archaic selfobjects, in which case the core of the self has remained poorly structuralized and vulnerable to disruption". Somehow she could feel that she can be understood in relation with me as a therapist. She reported that she felt good and surprised about how come she opened her real self with me. Since she needed this emphatic understanding, she reported the following sentences, at the end of the interviews implying that her mirroring needs were met.

Transcript Nihal- 14: Believe me, I cannot cry neither at home nor with someone or a neighbor. Since I don't want Dilek to see me, I cannot cry anywhere. Actually, my feelings are so complicated, I cannot laugh where I should, I cannot cry where I should. It is strange but when I come here, in front of you, I cannot hold onto myself.

Before concluding this idea however, we will again return to Pinar's reaction to her earlier life experiences. Thus, wherever convenient, we asked Pınar the same other questions too, as; 'Have you had any other difficulties before and if yes, how did you cope with other difficulties before this experience?'; 'What would you tell about your relationship with your family members now and before?'; 'Can you remember and describe a time from your childhood that you lost something important to you?'.

\section{Case 2 (PInar continued)}

Transcript Pınar-9: I was born in Germany and lived there for 9 months with my parents. After 9 months, my parents brought me in Turkey to live with my grandparents until I was 8 years old. With them, I had a life with full of love. I mean in my childhood. I have my grandmother, my cousins, my aunt,...with this small family I was so happy. Suddenly, my grandfather got health problems and my grandmother had to look after him. So, they had to take me to the Germany. Everything started after that. After such a beautiful, happy childhood, they put me in a car. At those times around 70's, going to Germany was done by car. It was around 1975-1976. So I got into the car and went to the Germany.

When I asked her about her earlier childhood family relations, naturally she started to talk about her grandparents because she was grown up with them. She described a happy childhood where she was loved very much. Her selfobject needs seemed to be satisfied. Then, she explained her critical life event that potentially could change her life and her relationships.

Transcript Pinar-10: I knew who my parents were but I called my grandparents as mother and father. My parents were visiting me with lots of presents. A woman and a man were coming. They were giving presents, they were walking me around, but, I didn't want to go around with them because I was attached to my grandparents. After such a beautiful childhood, I met with a kind of mother and father who internalized that kind of despotic German culture.

So, as Nihal, Pinar described a similar event in which she experienced a separation from her selfobjects (grandparents, grand family, neighborhood, country,..) at a very early childhood. While, Nihal separated only from her sister by her marriage, Pinar separated from everything and joined a new culture which she defined as despotic. Following transcript highlights the difficulties after Pınar's arriving Germany.

Transcript Plnar-11: The next morning, my father gave me a sketch of the neighborhood and some money, described the neighborhood and sent me to the market. I never forgot that. That was the first day of my arrival in Germany. He said 'buy these' and left me in the street. I was a social child but my father didn't know that. I wouldn't do this to my child now, in a different country. So, I learned to stay on my feet, and learned to fight with life.

Pinar's 'fighting-coping with life' attitude seemed to affect all her following difficult life experiences 
including her child's cancer diagnose and treatment. Even though she reasoned this attitude with her German style education which teaches her to stay on her own feet, it was seen that her earlier well-established relationships render this transition easier.

Transcript Pinar-12: Here, people find happiness from sadness. They found a common ground here. For example, these old women were helping each other. One of them was telling to the other that 'others don't understand you; people here take care of each other'. I liked those ideas. We are in the same room now and if we have a problem we will be helping each other, our relatives can't come now. Others can't understand.

From these transcripts and during interviews my feelings were as such; Nihal was affected more deeply and had more relationship problems than Pinar during these life difficulties. Even though Pınar was thinking same as Nihal about the impossibility of understanding of people who do not experience this event, she was benefiting from people who were in the same boat. She can experience twinship with others in hospital setting but Nihal wasn't able to do this. Nihal also mentioned that only people in this setting can understand her but somehow she did not want to share anything with them. That avoidance causes her stay disintegrated and in anxiety which necessitates constant reassurance or mirroring.

Beside twinship experience, Pınar seemed to benefit from people who have wisdom or experience in times of distress because she seemed to have a well established idealization with her father and others in her family. She was admiring and trusting her father as she described below.

Transcript Pinar-13: My relationship with my father is so good. He reads a lot. He improved himself very much. He is my best friend. I love him a lot. I always ask his ideas about things. He directs me. $\mathrm{He}$ is always calm and easy. He does not exaggerate anything. These days, I learned from him how to stay calm, not to worry too much...........and then, I talked to my psychologist friend and to a religious person. They both suggested me to tell myself that 'it is going to get better' and it got better...... They are from different areas but told the same thing. Then, I observed this from my father too. He was doing this already. So I had to do it.

\section{DISCUSSION}

'The concept of the selfobject is the most important contribution to the investigation and treatment of psychological life since Freud discovered psychoanalytic method and the significance of the transference' (32, p.1). It was used mostly in individual psychotherapeutic sessions where the aim was to resolve the individual's arrested development. However, there is very limited research where this concept could be applied other than psychotherapy patients.

Anyone at our environment can come across with cancer diagnose and treatment. It does not choose only people who have stable self cohesion. If people have an unstable self cohesion, new trauma can be experienced quite differently than people with comparatively stable sense of self cohesion. Thus, it is important to identify those vulnerable mothers in order to make proper intervention on mothers.

Kohut talked about some parents (7), 'who are unable to respond their children's changing narcissistic requirements... because they [use] their children for their own' (p. 274). Lee (33) called this with the term "reverse selfobject needs". He explained that as "being a selfobject of others when at the same time there is an urgent and appropriate need to have one's own selfobject needs met". In our case Nihal, while she played the idealized mother in order to be seen by her children, she missed the need of Dilek who also needs to be seen by appropriate responses. Thus, the child also served as an archaic selfobject needs for her mother. Lee (33) said that, it is not the trauma itself but the absence of adequate responsive selfobject responses from the "key" other determines the extent of traumatization. If the mother has energizing resources outside the mother/infant dyad, she can function as selfobject for the child (31) but the infant usually depends only on the mother's responsiveness and absence of mother's optimal mutuality would likely to cause trauma in the infant 
(18). Thus, in order to provide mutuality in mother/infant dyad and to protect the child from traumatized by being an excessive reverse selfobject for the mother, the mother's needs to be nurtured by the mutually responsive selfobject experience outside the mother-child dyad. Thus, to help a parent who needs emotional ties from others, we as selfobject therapist must be ready to be an idealized, mirroring or twinship selfobjects for the mothers who were traumatized by these responses.

\section{CONCLUSION}

Comparing two mothers, both Nihal and Pinar seemed to be affected from this traumatic event but while Nihal described the situation as crumbling, Pınar defined it only as disturbing. So, even both mothers have reported their selfobject needs, Nihal seem to disintegrate more easily. We suggest that the difference between these mothers' responses lies in the Nihal's deficiently formed self cohesion.

As a result, while in Pınar's narrative, there was no attribution about the therapist's responsiveness, Nihal mentioned her being understood by me very often. In practice, it is believed that responding those archaic deficits in an appropriate manner would be helpful for this mother.

\section{Strength, limitations and suggestions for the future research}

This study is the first about investigating psychoanalytically and developmentally oriented 'selfobject' concept of the caregiver mothers in cancer settings. Understanding 'selfobject needs' during traumatic experiences such as having a child with cancer leads us to identify vulnerable caregivers who have deficitly formed self cohesion. Besides, using narratives of the mothers who are in the process of getting treatment of their children's illness, sheds light on the real life stories of those people's difficulties. Without understanding the impact of this traumatic experience in relation to their earlier life experiences, it would be restrictive to understand those who experience these difficulties. Thus, from the practitioners' point of view, the idea of applying developmental theories to understand unique traumatic experiences of people is one of the most important strength of the study.

However, even though personal narratives are rich tools in understanding the individual's self-cohesion, investigating more cases' experiences would enlighten the subject better.

Selfobject concept is relatively new in scientific research area. Future studies should include more individuals in order to understand diverse presentation of those self experiences. Thus, using qualitative methods to understand the presentations of these needs in different life experiences or life tasks would give important information in understanding human psyche.

Correspondence address: PhD., Sema Yurdusen, Hacettepe University Medical Faculty, Pediatric Oncology Department, Ankara,Turkey, sema.yurdusen@hacettepe.edu.tr 


\section{REFERENCES}

1. Pöder U, Ljungman G, von Essen L. Parents' perceptions of their children's cancer-related symptoms during treatment: a prospective, longitudinal study, Journal of Pain and Symptom Management 2010; 40: 661-670.

2. Fletcher PC, Clarke J. When your child has cancer: a discussion of factors that affect mothers' abilities to cope, Journal of Psychosocial Oncology 2003; 21: 81-99.

3. Wolf ES. Treating the Self. New York: Guilford Press; 1988

4. Kohut H. How Does Analysis Cure? USA: The University of Chicago Press; 1984

5. Kohut H. The Analysis of the Self. International Universities Press, New York; 1971

6. Ornstein, P. Heinz Kohut's self psychology-and oursTransformations of Psychoanalysis, International Journal of Psychoanalytic Self Psychology 2008; 3: 195-214.

7. Kohut $\mathrm{H}$. The Restoration of the Self. International Universities Press, New York; 1977

8. Ettensohn M. The relational roots of narcissism: Exploring relationships between attachment style, acceptance by parents and peers, and measures of grandiose and vulnerable narcissism, Wright Institute Graduate School of Psychology, USA; 2011

9. Togashi K, Kottler A. The many faces of twinship: From the psychology of the self to the psychology of being human, International Journal of Psychoanalytic Self Psychology 2012; 7: 331-351.

10. Vipond C. The Development of Two Scales to Measure Selfobject Needs. (Unpublished dissertation). University of Windsdor, Ontario, Canada; 1987

11. Brothers D. Toward a Psychology of Uncertainty: TraumaCentered Psychoanalysis. New York: The Analytic Press; 2008

12. Geist R. Mini-analysis and idealizing transferences: Autobiographical reflections on the development of the therapeutic model, International Journal of Psychoanalytic Self Psychology 2008;3: 320-331.

13. Hershberg SG. Narcissus revisited: A link between mirroring and twinship selfobject experiences-A discussion of Nancy VanDerHeide's, 'A Dynamic systems view of the transformational process of mirroring', International Journal of Psychoanalytic Self Psychology, 2011; 6: 58-66.

14. Van Der Heide N. A dynamic systems view of the transformational process of mirroring, International Journal of Psychoanalytic Self Psychology 2009; 4: 32-444.

15. Brown S. Companion animals as selfobjects, Anthrozoös 2007; 20 (4): 329-343.

16. Lokhmotov R. Addiction as selfobject: an integrated analysis of self psychological and neurobiological models of nicotine addiction, (Unpublished dissertation), Institute for the Psychological Sciences, US; 2014

17. Kabat R. A role-reversal in the mother-daughter relationship, Clinical Social Work Journal 1996; 24: 255-269.

18. Lee R.R. An infant's experience as a selfobject, American Journal of Psychotherapy 1999;53:177-187.
19. Allen KD. Selfobject needs, Homophobia, Heterosexism, Among Gay Men During Emerging Adulthood, Walden University, USA; 2011

20. Brewer-Johnson AM. A qualitative method to evaluate sense of selfobject experiences in mothers of children with autism, California School of Professional Psychology at Alliant International University, San Diago, USA; 2005

21. Murray M. Narrative Psychology and Narrative Analysis. In Camic, P.M., Rhodes, J.E., Yardley, L. ed. Qualitative Research in Psychology: expanding perspectives in methodology and design. Washington: APA; 2003, pp. 95-112.

22. Riessman CK. Narrative, Memory and Everyday Life, Narrative Analysis, In Lewis-Beck, M.S., Bryman, A., Futing, L. (eds) The SAGE Encyclopedia of Social Science Research methods; 2003

23. Bamberg M. Why narrative? Narrative Inquiry 2012;22: 202210.

24. Lincoln YS. Guba, E.G. Naturalistic Inquiry. Newbury Park, CA: Sage Publications; 1985

25. Clandinin DJ, Connely FM. Narrative Inquiry: Experience and story in qualitative research. San Francisco: Jossey-Bass, Inc.; 2000

26. Loh J. Inquiry into issues of trustworthiness and quality in narrative studies: A perspective. The Qualitative Report 2013; 18:1-15.

27. Hagman G. Chapter 12 Death of a Selfobject: Toward a Self Psychology of the Mourning Process 1995; 11: 189-205.

28. Riessman CK. Strategic uses of narrative in the presentation of self and illness: A research Note, Social Science and Medicine 1990;30:1195-1200.

29. Banai E, Mikulincer M, Shaver PR. "Selfobject" needs in Kohut's Self Psychology, Links with attachment, self-cohesion, affect regulation, and adjustment, Psychoanalytic Psychology 2005;22:224-260.

30. Riessman, C.K. Life events, meaning and narrative: the case of infidelity and divorce, Social Science and Medicine 1989;29: 743-751.

31. Ungar MT, Levene JE. Selfobject functions of the family: Implications for the family therapy, Clinical Social Work Journal 1994;22:303-316.

32. Basch M. The selfobject concept: Clinical implications. In A. Goldberg (Ed.). A decade of progress: Progress in self psychology, Vol. 10, Hillsdale, NJ: The Analytic Press; 1994, pp. 1-7.

33. Lee RR. The reverse selfobject experience, American Journal of Psychotherapy 1988;17: 416-424. 